\title{
ASSESSMENT OF NUTRITIONAL STATUS OF PRIMARY SCHOOLS PUPILS IN MOSUL CITY
}

\author{
Bayda A. Yahya Suha J. Abdul - Lattef Sanna T. Ahmed \\ College of Nursing, Mosul of Univ.,Iraq
}

\begin{abstract}
For a period of nine months (October 2003-June 2004), 927 pupils of primary schools, (males and females) in Mosul City were assessed for their nutritional status using nutritional methods and measurements including nutritional history, physical examination (standard chart of weight and height, body mass index) in addition to laboratory estimation of hemoglobin level in blood due to malnutrition. The study aimed at identifying nutritional problems and deficiencies in which nutritional intervention is essential for recovery. The study showed that $58 \%$ of primary school pupils were in normal state of nutrition, the remaining $41.7 \%$ complaining from malnutrition, $33 \%$ of them have mild degree, $1.2 \%$ with moderate malnutrition, while over weight diagnosed in $7.5 \%$ of student. There were no significant difference between pupils from different socioeconomic levels regarding malnutrition, while over weight showed a high percentage among moderate level group. Related factors to pupils nutritional health diagnosed by this study as: improper nutritional school programs, unhealthy dietary habits among pupils, deficit nutritional educational programs. It has been found that $66 \%$ of mild malnourished pupils complaining of anemia. The study suggest a more frequent nutritional surveys at different community's levels, with improvement of nutritional educational programs that emphasize school family participation.
\end{abstract}

\section{INTRODUCTION}

Good nutrition is an essential part of good health, poor nutrition by itself or that associated with infectious diseases account for a large portion of the world's disease burden (Stanhop and Lancaster, 2004).

Nutrition has a major area of focus for health promotion of school age children it is important that the increasing energy requirements coming with this age are met daily with foods of high nutritional value (Pillitteri , 1999). School age children need a well balanced diet, average 2400 calories per day that is required to meet growth needs, as the child size increases, the amount of food needed also increases (Edelman and Mandle ,1998)

Assessment of nutritional states is an important component in the diagnosis of nutritional problems, the basis of the assessment rests on history, physical examination and laboratory evaluation ( Smiltzer and Bare, 2001).

The main nutritional related problems in school age children are stunting growth: low height and weight for a given age, anemia, obesity, poor dental health, common dietary deficiencies: iodine, vitamin A, calcium deficiency. Monitoring community for health and nutrition of different age groups of 
children can help to identify and diagnose different nutritional problems (Macmillan , 1998).

Received 23/6/2005. Accepted $23 / 11 / 2005$ 
The Specific practices and beliefs influencing eating habits commonly caused nutritional problems in school-age adolescents are skipping of one or more meals each day, inappropriate choices of snack food (candies, soft drinks, corn and potato chips), lack of supervision in foods choices made away from home, fear of obesity especially among girls, concern that certain foods would aggravate acne. lack of time to consume regular meals, don't drink milk, tradition ethnic food, family budget, peer pressure and preference for some food, dislike for other (Merki, 1996). Relatively little research have been done on the nutritional needs and problems of people from (4-16) year of age because few nutritional problems identified among such group, there is a little information that help to judge the long term consequences of specific eating pattern during childhood and adolescence.

The aim of the study is to conduct a nutritional assessment for pupils of primary schools with specific age group (6-11) year, in order to identify the main nutritional problems and deficiencies in which nutritional intervention is essential for recovery with a specific objectives of :

1. Identifying the nutritional problem among primary school pupils by nutritional assessment.

2. Assessing factors related to nutritional health of pupils.

\section{MATERIALS AND METHODS}

Descriptive study conducted over a period of 9 months starting in October 2003 till June 2004 includes nutritional assessment of 927 pupils in primary schools aging 6-11 year. This sample taken from three different socioeconomic areas (high, moderate and low) to represent the whole community of Mosul city.

Both schools and pupils were selected randomly 103 pupils from each school - (18) pupils from each class.

The nutritional assessment designed for evaluating three aspects of all over nutrition. Protein energy and micronutrient balance by using the main three methods:

1. Nutritional history.

2.Appropriate physical examination with simple anthropometric measurements.

3. Laboratory investigation.

Nutritional history for detecting factors that could influence general health and produce future nutritional problem, for this aim a specially designed questionnaire was performed to cover a wide range of information after it has been checked and examined from different experts, pupils were fill this form with the help of their parents and families (Appendix I).

Anthropometric measures which adopted in study include;

a. For each pupil weight was measured by using electrical balance, height was measures by using vertical scale, both compared with standard growth curves of National Center for Health Statistics / Center of Disease Control ( NCHS /CDC ) published-(1989) based on weight and for height. 
b. Body Mass Index: Body mass index (BMI): is the preferred means of expressing weight relative to height so it is useful in the assessing both under and over weight and widely used in estimating energy balance.

Mesopotamia J. of Agric

(ISSN 1815-316 X)

2005

Vol. ( 33 ) NO ( 4 )

Normograms and charts available to determine BMI by dividing weight in kilogram by height in meter squared $(\mathrm{Kg} / \mathrm{m} 2)$, normal BMI ranging from 19-25 (Edelman and Mandle, 1998).

Laboratory assessment: focused on potential deficiencies identified by history and physical examination.

Estimation of blood hemoglobin concentration done to diagnose specific nutritional anemia by using Laboratory technique "spectrophotometer method" for malnourished pupils.

$\mathrm{HB}<12 \% \mathrm{~g} / \mathrm{L}$ indicate the presence of anemia (Stanley, 1998).

Chi- square was used to analysis data statically in addition to frequency and percentage.

\section{RESULTS AND DISCUSSION}

Table (1) gives the distribution of 927 pupils in regard to Gomes classification and shows that $58 \%$ of school children age $(6-11)$ year in mosul city were in normal nutritional state in which nutritional deficiency was rare among healthy children live in the industrialized nation, as it is found by (Williams, 1999).

Table (1): Distribution of (927) pupils according to (*)Gomes classification

\begin{tabular}{|c|c|c|c|c|c|c|c|c|c|c|}
\hline \multirow{3}{*}{$\begin{array}{l}\text { Age in } \\
\text { Year }\end{array}$} & \multicolumn{10}{|c|}{ Nutritional Status } \\
\hline & \multicolumn{2}{|c|}{$\begin{array}{c}\text { Normal } \\
\text { nutrition }\end{array}$} & \multicolumn{2}{|c|}{$\begin{array}{c}\text { Mild } \\
\text { malnutrition }\end{array}$} & \multicolumn{2}{|c|}{$\begin{array}{c}\text { Moderate } \\
\text { malnutrition }\end{array}$} & \multicolumn{2}{|c|}{$\begin{array}{c}\text { Sever } \\
\text { malnutrition }\end{array}$} & \multicolumn{2}{|c|}{ Over weight } \\
\hline & No. & $\%$ & No. & $\%$ & No. & $\%$ & No. & $\%$ & No. & $\%$ \\
\hline $6-7 / 1^{\mathrm{st}}$ & 119 & 13 & 25 & 2.5 & 6 & 0.6 & - & - & 13 & 1.4 \\
\hline $7-8 / 2^{\text {nd }}$ & 110 & 12 & 35 & 3.7 & 4 & 0.4 & - & - & 3 & 0.3 \\
\hline $8-9 / 3^{\text {rd }}$ & 83 & 9 & 61 & 6.5 & 2 & 0.2 & - & - & 12 & 1.2 \\
\hline $9-10 / 4^{\text {th }}$ & 70 & 7.5 & 64 & 7 & - & - & - & - & 5 & 0.5 \\
\hline $10-11 / 5^{\text {th }}$ & 72 & 7.7 & 60 & 6.5 & - & - & - & - & 11 & 1.1 \\
\hline $11-12 / 6^{\text {th }}$ & 81 & 8.7 & 66 & 7 & - & - & - & - & 25 & 2.6 \\
\hline Total & 535 & 58 & 311 & 33 & 12 & 1.2 & - & - & 69 & 7.5 \\
\hline
\end{tabular}

The Remaining $41.7 \%$ have different degree of malnutrition $33 \%$ have mild malnutrition, $1.2 \%$ with moderate malnutrition which agree with another study conducted in Baghdad in 1996 showed that $18.5 \%$ of school children were under weight (Yonis and Al-bawee, 1999 ) this reflected clinically on 
their weight and height because rapid growth and development at this age lead to frequent nutritional needs.

Malnutrition more frequent among young children at $6-9$ year of age, this due to the fact that preschool and young children in developing countries are particularly susceptible because of their dependence on others for foods, their

Mesopotamia J. of Agric

(ISSN 1815-316 X) 2005

Vol. ( 33 ) NO ( 4 )

higher protein and energy requirement and their enhanced susceptibility to infection specially under non hygienic conditions (Williams, 1999).

Over weight detected in $7.5 \%$ of pupils, their excess body weight affect body and may progress to obesity which multifactorial problems involve inherited tendency, over eating, lack of physical activity (Merki, 1996).

Although children in poverty have less access to nutrious food and health care, on studying socioeconomic state of each pupil as in table (2).

Table (2): distribution of pupils according to nutritional and socioeconomic state.

\begin{tabular}{|c|c|c|c|c|c|c|c|c|c|c|}
\hline \multirow{3}{*}{$\begin{array}{c}\text { socioeco } \\
\text { nomic } \\
\text { level }\end{array}$} & \multicolumn{10}{|c|}{ Nutritional Status } \\
\hline & \multicolumn{2}{|c|}{$\begin{array}{l}\text { Normal } \\
\text { nutrition }\end{array}$} & \multicolumn{2}{|c|}{$\begin{array}{c}\text { Mild } \\
\text { malnutrition }\end{array}$} & \multicolumn{2}{|c|}{$\begin{array}{l}\text { Moderate } \\
\text { malnutrition }\end{array}$} & \multicolumn{2}{|c|}{$\begin{array}{c}\text { Sever } \\
\text { malnutrition }\end{array}$} & \multicolumn{2}{|c|}{$\begin{array}{c}\text { Over } \\
\text { weight }\end{array}$} \\
\hline & No. & $\%$ & No. & $\%$ & No. & $\%$ & No. & $\%$ & No. & $\%$ \\
\hline High & 173 & 18.5 & 98 & 10 & 2 & 0.2 & - & - & 2 & 1.2 \\
\hline Moderate & 183 & 20 & 112 & 12 & 4 & 0.4 & - & - & 50 & 5.3 \\
\hline Low & 179 & 19 & 101 & 11 & 6 & 0.6 & - & - & 7 & 0.7 \\
\hline Total & 535 & 58 & 311 & 33 & 12 & 1.2 & - & - & 69 & 7.5 \\
\hline
\end{tabular}

$\mathrm{X} 2=44.91$

It showed no significant effect of socioeconomic level of pupils on their nutritional state which is based on a standardized and similar eating practices in our community with a similar essential nutritional meals provided by government for all members. Over weight shown in $5.3 \%$ of pupils with moderate socioeconomic level.

Table (3) illustrate characteristics of a selected sample of 927 pupils, it showed that both sexes( males and females) were susceptible to develop nutritional problems with an equal chance of being malnourished as it is found by (Stanhope and Lancaster,2004).

$23.4 \%$ of malnourished children belong to big extended families with a large number of children within these families with a secondary level of education for both parents and limited income.

Assessment of factors related to nutritional health of pupils as shown by table (4), $90 \%$ with improper nutritional school programs that is reflected on pupils nutrition as they spent a lot of hours at school every day, improving school nutrition to meet the general cost and the nutritional need of pupils should be taken in consideration (Nise and McEwan, 2001). 
Unhealthy eating habits and wrong nutritional practices diagnosis by nutritional history taken from the pupils and their parent, excess tea intake in $67 \%$, low consumption of fruits and vegetables in $60 \%$, Poor personal hygiene in $45 \%$, and infrequent meals of beans in $35 \%$, Excess sweets intake in $25 \%$, all these practices were deeply related to social and educational level of parents and the living pattern described by (Al- Ghadanphary, 1990). $43 \%$ of pupils have poor nutritional advices and education mainly at school level which affect the performance and nutritional state of primary school pupils

(Abdul- Jabar, 2004 ).

Mesopotamia J. of Agric

(ISSN $1815-316 \mathrm{X}$ ) 2005

Vol. ( 33 ) NO ( 4 )

Table (3): Characteristics of primary school pupils selected for the study

\begin{tabular}{|l|c|c|c|}
\hline \multirow{2}{*}{\multicolumn{1}{|c|}{ Characteristics }} & \multicolumn{3}{|c|}{ Nutritional Status } \\
\cline { 2 - 4 } & Normal \% & Malnutrition \% & Over Weight \% \\
\hline Sex & & & 4.5 \\
\hline Male & 30.8 & 19.7 & 3 \\
\hline Female & 27 & 13 & 3.5 \\
\hline Family Size & 34.4 & 23.4 & 4 \\
\hline Big (Expanded) & 23.5 & 9.2 & 1.2 \\
\hline Small (Nuclear) & & & 4 \\
\hline Mother's Education & 29 & 11.3 & 2.3 \\
\hline Illiterate or primary & 23.5 & 16.5 & 1 \\
\hline Secondary & 7 & 5.2 & 4 \\
\hline Higher & & & 2.5 \\
\hline Father's Education & 14.5 & 13.5 & - \\
\hline Illiterate or primary & 25.8 & 14 & 3.3 \\
\hline Secondary & 17.5 & 6.2 & 4.2 \\
\hline Higher & & & \\
\hline Work of Father & 15 & 19 & 13 \\
\hline Have no work & 19 & 11 & \\
\hline Gainer & 24 & & \\
\hline Employed & & & \\
\hline
\end{tabular}

Table (4): Factors related to pupils nutritional health expressed in percentage.

\begin{tabular}{|l|l|c|}
\hline & \multicolumn{1}{|c|}{ Factors } & $\%$ \\
\hline 1. & Improper school nutrition programs & 90 \\
\hline 2. & Unhealthy Dietary Habits: & \\
\hline & - Excess tea intake & 67 \\
\hline & - Low fruits and vegetables intake & 60 \\
\hline & - Poor personal hygiene & 45 \\
\hline & - Infrequent meals of beans & 35 \\
\hline & - Excess sweets intake & 25 \\
\hline & - Skipping meals especially breakfast & 23 \\
\hline 3. & Inadequate nutritional advice & 43 \\
\hline
\end{tabular}




\begin{tabular}{|l|l|c|}
\hline 4. & Family problems & 18 \\
\hline 5. & Chronic illness of child & 9 \\
\hline
\end{tabular}

Problems within the families present in $18 \%$ of pupils, some with single parent other with lack of social and emotional support, on other side chronic illness in $9 \%$ of pupils affect their nutritional state because it reduce dietary intake as a result of anorexia with an increase demand for energy or as result of drug therapy, this illness like chronic renal problems, thalassemia, congenital heart diseases, chronic parasitic infection (Al- Ghadanphary, 1990).

Anemia could be the out come of poor nutrition that affect physical activity and intellectual capacity of children to learn in school, or could be the cause of

Mesopotamia J. of Agric

(ISSN 1815-316 X) 2005

Vol. ( 33 ) NO ( 4 )

malnutrition as it is affect child appetite with lessened desire to eat (Stanhope and Lancaster, 2004).

Table(5) reveals that $66 \%$ of pupils with mild malnutrition have mild anemia (blood hemoglobin < $12 \mathrm{~g} / \mathrm{dl}$ ), while sever anemia ( blood hemoglobin $<7 \mathrm{~g} / \mathrm{dl}$ ) found mainly among moderate malnourished pupils. This mean that there is a strong relationship between anemia and malnutrition in school age pupils (Abdul -Jabar, 2004).

Table (5): Frequency of anemia among malnourished pupils.

\begin{tabular}{|c|c|c|c|c|c|c|c|c|}
\hline \multirow{2}{*}{ Blood hemoglobin } & \multicolumn{7}{|c|}{ Nutritional Status } \\
\cline { 2 - 10 } & $\begin{array}{c}\text { Mild } \\
\text { malnutrition }\end{array}$ & \multicolumn{2}{c|}{$\begin{array}{c}\text { Moderate } \\
\text { malnutrition }\end{array}$} & \multicolumn{2}{c|}{$\begin{array}{c}\text { Sever } \\
\text { malnutrition }\end{array}$} & \multicolumn{2}{c|}{$\begin{array}{c}\text { Over } \\
\text { weight }\end{array}$} \\
\cline { 2 - 10 } & No. & $\%$ & No. & $\%$ & No. & $\%$ & No. & $\%$ \\
\hline Normal $\mathrm{Hb}>12 \mathrm{~g} / \mathrm{dl}$ & 103 & 33 & - & - & - & - & - & 69 \\
\hline $\mathrm{Hb}<12 \mathrm{~g} / \mathrm{dl}$ & 205 & 66 & 10 & 83 & - & - & - & - \\
\hline $\mathrm{Hb}<10 \mathrm{~g} / \mathrm{dl}$ & 3 & 0.9 & - & - & - & - & - & - \\
\hline $\mathrm{Hb}<7 \mathrm{~g} / \mathrm{dl}$ & - & - & 2 & 16.6 & - & - & - & - \\
\hline Total & 311 & & 12 & & & & & 69 \\
\hline
\end{tabular}

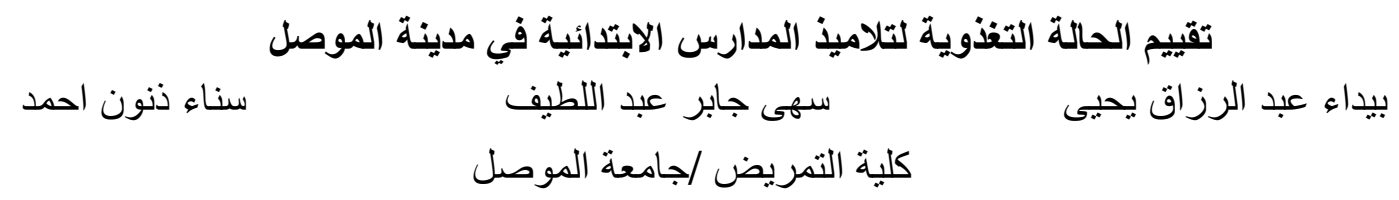

الخلاصة

تم اجر اء تقييم تغذوي لـ لو و تلميذ في الددارس الابتدائية لمدينة الموصل ذكوراً و وإناثأ خلال

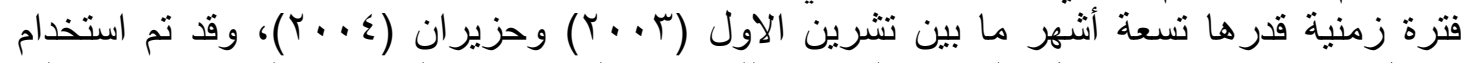

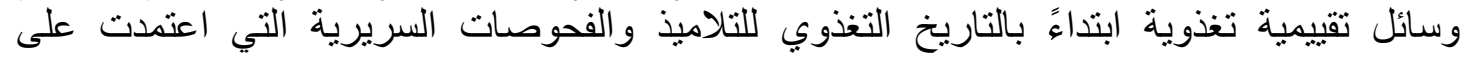

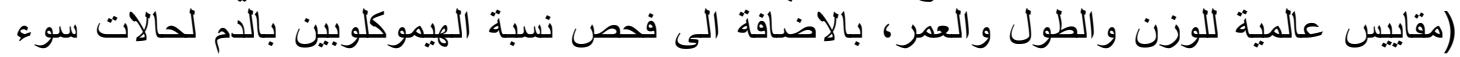

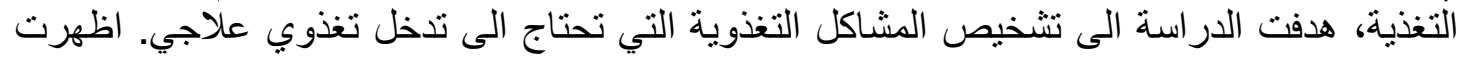

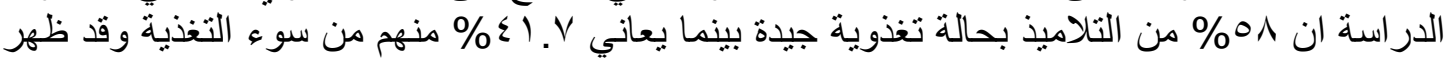




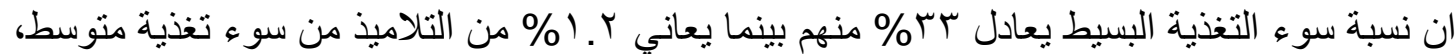

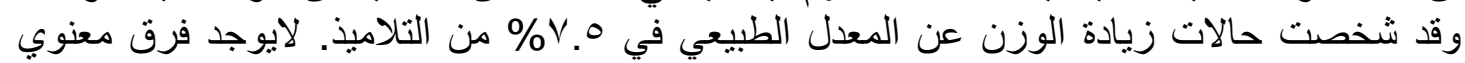

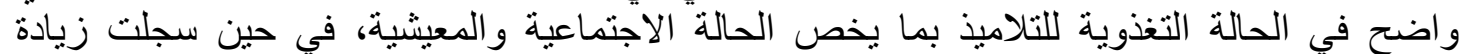

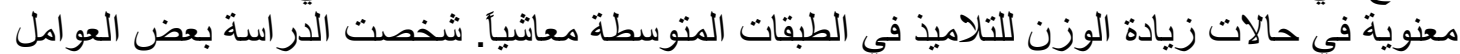
المتعلقة بالصحة الغذائية مثل عدم كفاءة البرامج الغذائية التغذوية، وجود التئة عادات تغذوية غير صحية صاتية

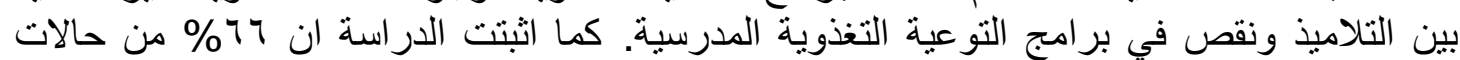
سوء التغذية البسيط يعانون من فقر الدئ البه البسيط.

\section{REFERENCES}

Abdul- Jabar, S. (2004). Effect of health education on the performance and nutritional status of primary school pupils , Nutritional survey, Ministry of Health, Primary Health Care Department, Iraq, Nineveh.

Mesopotamia J. of Agric (ISSN 1815-316 X)

Vol. ( 33 ) NO ( 4 ) 2005

Al-Ghadanphary, R. (1990). The size of diarrhea problem and factors affect it among children in Mosul city, Master thesis in community medicine, Mosul University .

Edelman, C. and C. Mandle (1998). Health promotion throughout the life span, $4^{\text {th }}$ Ed., Saunders Co. USA. p. 519.

Macmillan, C. (1988). "Nutritional handbook for community workers in the tropics", Monitoring community for health and nutrition of children nutritional" $2^{\text {nd }}$ Ed., Caribbean food and nutrition institute in collaboration with Ministry of Health, Jamaica, London, p. 136.

Merki, M. (1996). "Teen health, factors that influence adolescent diet", New York, McGraw-Hill, p. 261.

Nise, M. and M. McEwan, (2001). "Community health nursing, nutrition of school age children”. USA, Saunders Co., P. 361.

Pillitteri, A. (1999). "Maternal and child health nursing, promoting nutritional health for the adolescent, $3^{\text {rd }}$ Ed., Philadelphia USA, p. 884.

Sadek, A. (1992). Assessment of malnutrition state in kindergarten less than 5 years in Malta village - Dohuk, master thesis, Medical College , Mosul University.

Smiltzer, S. and B. Bare (2001). "Medical surgical nursing, nutritional assessment", $9^{\text {th }}$ Ed. Philadelphing Lippincott Co., P. 60-62.

Stanhop, M. and J. Lancaster (2004). "Community health nursing, nutritional and world health", $6^{\text {th }}$ Ed., Chicago, Mosby Co., p. 625.

Stanley, L. (1998). "Clinical laboratory tests values and implications", USA, Springhouse; p. 335.

Williams, S. (1999). "Essentials of nutrition and diet therapy". $7^{\text {th }}$ Ed., USA, Mosby Co., p. 313.

Yonis, N. and S. Al-Bawee (1999). Growth retardation among school children during the economic sanction in Baghdad city, Sci. J. Nurs. Vol. 12, No.2. 



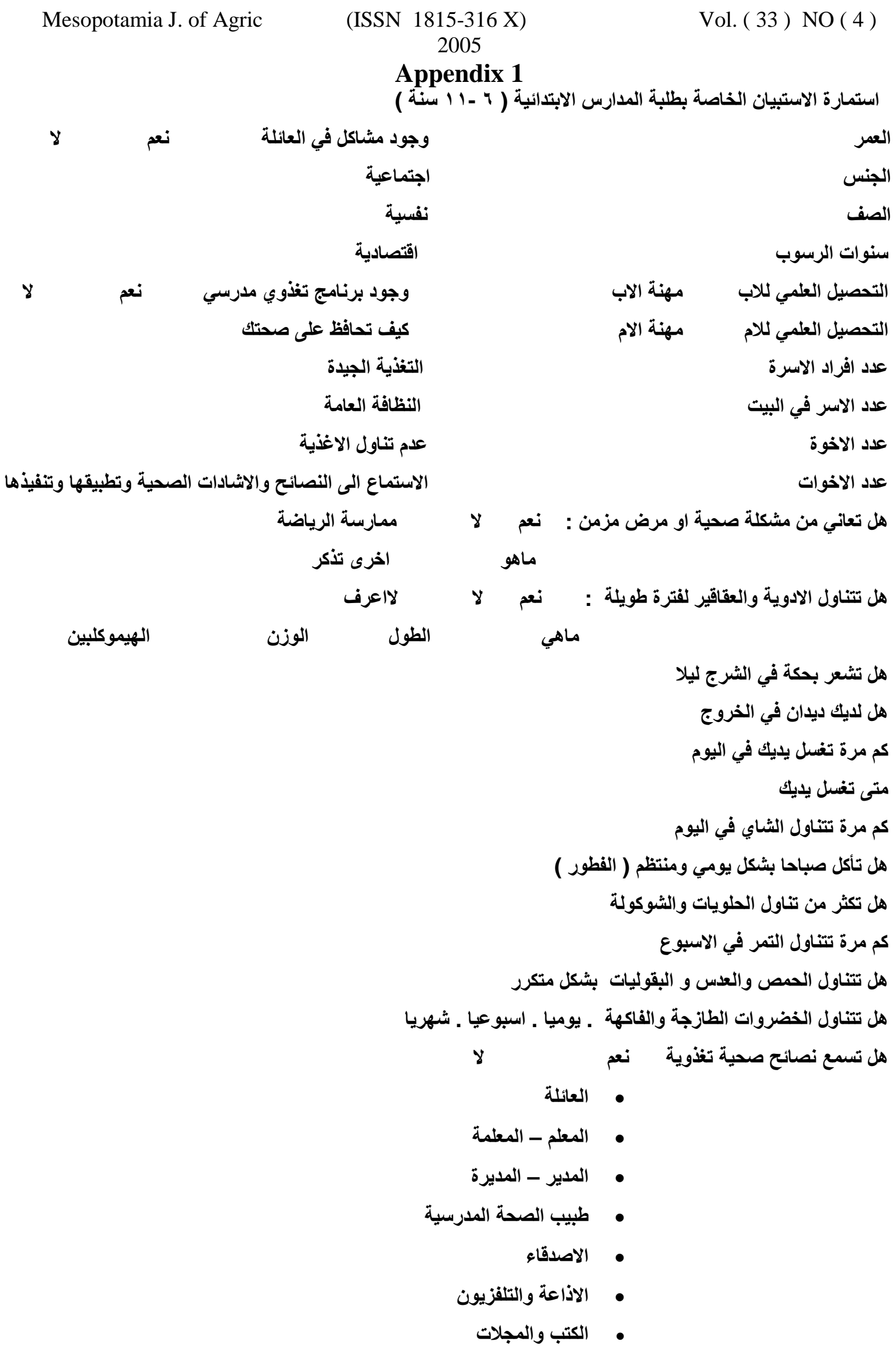

